\title{
Otoczony obfitością nicości. Antropologia rzeczy w zbiorze esejów Andrzeja Stasiuka Wschód (2014)
}

\author{
Agnieszka Janiec-Nyitrai (Budapešt')
}

\begin{abstract}
Abstrakt
Celem tekstu jest analiza zbioru esejów polskiego pisarza Andrzeja Stasiuka Wschód (2014) w kontekście szeroko pojętej antropologii rzeczy. Stasiuk w swoich esejach poświęca uwagę najważniejszym problemom współczesności - zwraca uwagę na zmiany relacji między człowiekiem a przedmiotem, w negatywny sposób ocenia dominujący obecnie konsumpcyjny styl życia, za pośrednictwem oryginalnego podejścia do świata przedmiotów analizuje stosunek współczesnego człowieka do przeszłości. Pokazuje przedmioty, które mogą być „milczącymi świadkami” tragicznych, traumatycznych zdarzeń, np. holocaustu. Polski eseista bacznie obserwuje również zmiany zachodzące w kulturze Europy Środkowej po roku 1989. Ważne miejsce zajmują w jego esejach także kwestie autentyczności i prawdziwości ludzkiego życia, a właśnie stosunek człowieka do przedmiotów odzwierciedla pewne zmiany, które da się na tej płaszczyźnie zauważyć. Na podstawie analizy poszczególnych esejów autorka spróbuje również scharakteryzować antropologię rzeczy w pojęciu Andrzeja Stasiuka.
\end{abstract}

\section{Klíčová slova}

Andrzej Stasiuk; współczesna literatura polska; antropologia rzeczy

\section{Abstract \\ Surrounded by the Abundance of Nothingness. Anthropology of Things in Andrzej Stasiuk's Essay Collection East (2014)}

The aim of the paper is to analyze the collection of travel essays East (2014) written by Polish writer Andrzej Stasiuk in the context of the broadly conceived anthropology of things. Stasiuk in his essayistic texts, touches upon the most fundamental problems of the present times - he perceives the transformation of human relationship to things, negatively evaluates the growing consumer style of life, and he also analyzes the human relationship to the past through the peculiar anthropology of things. He depicts objects that can be "silent witnesses" to tragic, traumatic events such as the Holocaust. Last but not least, the Polish essayist also follows the transformations of Central European society after 1989. Important questions concerning the authenticity and truth of human life are also touched upon in the paper. The human attitude to things reveals certain changes in society that can today be traced. Based on the analysis of individual texts, the author of the study will also try to characterize Stasiuk's anthropology of things.

\section{Key words}

Andrzej Stasiuk; contemporary Polish literature; anthropology of things 


\section{Wstęp}

Celem artykułu jest przybliżenie ontologii i antropologii przedmiotów w esejach podróżniczych Andrzeja Stasiuka Wschód (2014). Przedmioty występują w tekście polskiego pisarza w rozmaitych konfiguracjach: jako towary, produkty i rzeczy oraz pełnią rozmaite funkcje, niemal zawsze jednak stają się punktem wyjścia do rozważań filozoficznych, podejmujących najważniejsze, fundamentalne pytania dotyczące obecności człowieka we współczesnym świecie. Podróże i obserwowanie nowego są dla Stasiuka jedynie impulsem do dalszych eksploracji mechanizmów rządzących społeczeństwem, do badań przeszłości, ludzkiej pamięci, przemian człowieka wystawianego na działania polityki, historii i kultury, chociaż mówi, że interesuje go geografia i świat sprzed pojawienia się człowieka. Podróżopisarstwo Stasiuka jest więc czymś więcej niż tylko przemierzaniem nieznanej dotąd przestrzeni, staje się podróżą w głąb świata, przepełnionego właśnie przedmiotami, które, jako wytwory ludzkich rąk, są w stanie ujawnić o wiele na temat kondycji współczesnego człowieka.

Norweski badacz i teoretyk kultury materialnej Bjørnar Olsen podkreśla, że rzeczy materialne współistnieją w świecie na równych prawach, jak ludzie, rośliny i zwierzęta, ${ }^{1}$ a więc badanie ich pozwala odsłonić wiele nowych, nieznanych współzależności istniejących w kulturze. Stasiuk zdaje się być niezwykle wyczulony na owe ukryte współzależności i intuicyjnie podąża w kierunku dającego się od kilkunastu lat zaobserwować we współczesnej humanistyce „zwrotu ku rzeczom”. Radykalną postać ów „zwrot ku rzeczom” przyjmuje np. w pracach polskiej badaczki Ewy Domańskiej. Postuluje ona potrzebę powstania humanistyki nie-antropocentycznej. ${ }^{2}$ Jednak w przypadku esejów Stasiuka ze zbioru „Wschód” uzasadnione wydaje się być pozostanie przy antropocentrycznej perspektywie, dlatego punktem wyjścia będzie dla nas antropologia przedmiotów w rozumieniu Tomasza Rakowskiego, ${ }^{3}$ czyli pozostająca w ramach badania związków i powiązań między rzeczami a człowiekiem.

Trzeba pamiętać, że rzeczy, przedmioty otaczające ludzi przestały już być wyłącznie epifenomenami, zjawiskami wtórnymi, nie są już tylko funkcją pewnych zjawisk społecznych i kulturowych, ale same mają pewnego rodzaju moc sprawczą wobec człowieka, kształtuja jego postawy i zachowania, jednocześnie zdradzając wiele o samym współczesnym człowieku uwikłanym w pułapki konsumpcjonizmu i tęskniącym jednocześnie za czymś oryginalnym, niepowtarzalnym. Rzeczy według Joanny Szydłowskiej: „Moga być ważnym elementem podmiotowej $i$ zbiorowej tożsamości, konstruować przestrzenie pamięci, a wchodzac w różnorakie interakcje z ludźmi, budować perspektywe do refleksji nad ich znaczeniem, wytwarzaniem, używaniem, konsumowaniem, udomawianiem, rozdawaniem, pozbywaniem sie, narratywizowaniem."4

1 OLSEN, Bjørnar: W obronie rzeczy. Archeologia i ontologia przedmiotów. Warszawa: Wydawnictwo Instytutu Badań Literackich PAN, 2013, s. 19.

2 DOMAŃSKA, Ewa: Humanistyka nie-antropocentryczna a studia nad rzeczami. Kultura Współczesna, 2008, nr 3, s. 10-13.

3 RAKOWSKI, Tomasz: Antropologia rzeczy: wprowadzenie. Kultura Współczesna, 2008, nr 3, s. 7-8.

4 SZYDŁOWSKA, Joanna: Retoryka rzeczy a proces zadomowienia w przestrzeniach pojattańskiego Okcydentu. Anthropos, 2011, nr 16-17, s. 127. 
„Powrót do rzeczy” lub „zwrot ku materialności” jest według Ewy Domańskiej naturalną reakcją na panujący w humanistyce dyskurs dekonstruktywizmu, konstruktywizmu i narratywizmu. ${ }^{5}$ Właśnie w zbiorze esejów Andrzeja Stasiuka da się doskonale zaobserwować ów powrót do rzeczy oraz jednoczesny powrót do rzeczywistości i do osadzonych w niej doświadczeń. Jeśli spojrzymy na pisarstwo Stasiuka w dłuższej perspektywie, wtedy okaże się, że pisarz w swoich wcześniejszych tekstach ów zwrot w humanistyce znacznie wyprzedził, a eseje ze zbioru „Wschód” dopełniają i zwieńczają drogę Stasiuka ku przedmiotom. ${ }^{6}$

W niniejszym artykule zaproponuję typologię „obfitości nicości” i postaram się uporządkować „wysypisko cudów” (s. 247), jak obrazowo pisze Stasiuk o przedmiotach i rzeczach, ${ }^{8}$ które widzi podczas swoich peregrynacji po Polsce, Rosji i Mongolii. Postaram się przedstawić relację między ludźmi a przedmiotami, ów nierozerwalny związek, który według Marka Krajewskiego realizuje się na wszystkich poziomach człowieczeństwa. ${ }^{9}$

\section{Współczesny postświat podróbek (s. 29) kontra dawny świat antykonsumpcji (s. 63)}

Jedna z cech nowoczesności jest nadmiar, jednorazowość i masowość. Symbolizuja ja wszechobecni Chińczycy i ich towary, które pozbawione są osobowości. Przedmiot staje się produktem, staje się bezosobowy, jest produkowany w milionach egzemplarzy, a każdy z nich jest w pewnym sensie nieautentyczny. Produkty te przypominaja falsyfikaty, są wytwarzane w ilościach przypominających nieskończoność (s. 189). Stasiuk demaskuje zwodnicze piękno masowej produkcji, jej kiczowatość i kłamliwość: „Wchodze do tych blaszanych bud wypetnionych badziwiem $i$ paździerzem $i$ btądze pośród fantomów, pośród odbić i mamień. Zaraz sie gubie, bo wszystko jest podobne, nieoczywiste i petne tego pótciemnego blasku, tej oszukańczej poświaty, w której nie sposób dostrzec prawdziwych ksztattów i kolorów rzeczy" (s. 63).

5 DOMAŃSKA, Ewa: Problem rzeczy we wspótczesnej archeologii. In: KOWALEWSKI, Jacek - PIASEK, Wojciech - ŚLIWA, Marta (eds.): Rzeczy i ludzie. Humanistyka wobec materialności. Olsztyn: Instytut Filozofii Uniwersytetu Warmińsko-Mazurskiego w Olsztynie, 2008, s. 31.

6 Ze względu na ograniczenia objętości tekstu temat ten jedynie sygnalizuję, zapewne warto by prześledzić wcześniejszą twórczość Stasiuka właśnie w kontekście antropologii przedmiotów, ale wykracza to poza ramy mojego artykułu.

7 STASIUK, Andrzej: Wschód. Wołowiec: Czarne, 2014, s. 228. Kolejne cytaty z książki i odnośniki do niej zaznaczone są bezpośrednio w tekście w nawiasie kwadratowym z podaniem numeru strony.

8 Na użytek tego artykuły będę traktować rzeczy i przedmioty synonimicznie, choć świadoma jestem pewnego uproszczenia z tym związanego, jednakże heideggerowskie rozróżnienie między owymi pojęciami (rzeczy jako obiekty użyteczne, charakteryzujące się poręcznością, narzędzia i przedmioty jak byty-tylko-obecne, obiekty materialne, obserwowane z dystansu i reprezentowane, por. HEIDEGGER, Martin: Rzecz. Odczyty i rozprawy. Kraków: Aletheia, 2002, s. 145-164), wprowadziłoby jedynie, jak mi się wydaje, niepotrzebne zamieszanie pojęciowe. Dlatego pojęciem przedmiot używam w rozumieniu polskiego badacza Marka Krajewskiego jako „rzecz wykonana przez cztowieka”. Por. KRAJEWSKI, Marek: Przedmiot, który ucztowiecza... Kultura Współczesna, 2008, nr 3, s. 43.

9 KRAJEWSKI, Marek: Przedmiot, który ucztowiecza... Op. cit., s. 44. 
Kupujący ludzie poruszają się jak zaprogramowane roboty, są zahipnotyzowani, odurzeni zapachem sztucznego kauczuku i impregnatów. Nadmiar jest tylko janusową twarzą ubóstwa, bowiem bieda u Stasiuka często przybiera formę nietrwałości, a sama rzeczywistość jawi się jako fatamorgana. ${ }^{10}$

Przedmioty zdradzają problemy współczesnego człowieka z rozchwianą, niestabilną tożsamością. Obserwując prostych chłopaków z Podlasia, Stasiuk dostrzega ich brak zakotwiczenia w rzeczywistości, ich niepewność i tymczasowość.

„Byli dziwnie ubrani. Zwtaszcza chtopaki. Pstrokato i od Sasa do Lasa. [...] Ale to byt pewnie lumpeks lub tania chinszczyzna. Wszystko jakieś niedobrane, niedopasowane, jakby znalezione. $Z$ napisami, naszywkami i hastami wszechświatowego wirtualu. [...] aniotowie postnowoczesnej ikonosfery. Szli przez optotki i kartofliska, pod niebem Syberii w dresiarskich szarawarach $i$ kapotach ostemplowanych emblematami globalnej wspólnoty. Przez piachy po kostki w kitajskich reebokach. Stare drewno, piach i potem od razu ten postświat podróbek" (s. 29).

Jednocześnie ubrania zdradzają cały ogrom zmian cywilizacyjnych - ludzie chcą stać się częścią zachodniego świata, pociąga ich globalna wspólnota, ale jednocześnie wszystko jest prowizoryczne, tanie, wszystko jest podróbką - zmiana jest jedynie powierzchowna, ubranie staje się schronieniem przed beznadzieją własnej egzystencji. Stasiuk pisze o ziejącej pustce po komunizmie, która zostaje naprędce wypełniana tanimi towarami z Chin. Młodzi ludzie pragną nadążyć za zmianami w świecie, ale wciąż są w pewien sposób zacofani, zadowalają się produktami zastępczymi, a nie autentycznymi.

Sam Stasiuk widzi siebie jako „dziecko niedoboru i reglamentacji” (s. 63), uważa się za syna świata antykonsumpcji (s. 63). Dlatego też pragnie jechać na Wschód, gdzie nadmiar nie zasłania tego, co najistotniejsze, gdzie wśród śmieci, kurzu, brudu i piasku wyłania się i objawia pewna prawda o świecie (s. 114). Ważny wymiar ma w tym kontekście doświadczanie nicości, bezkresu niewypełnionego rzeczami. ${ }^{11}$ Stasiuk wspomina swoje dzieciństwo, kiedy brak rzeczy sprawiał, iż ludzie nie byli niewolnikami konsumpcji, a teraz pragną zrekompensować sobie dawny brak nadmiarem, ale nadmiar ten jest biedny, tani, smętny i banalny: „Torby w krate i plastik udajacy skórę. Zwaty tego wszystkiego. Tej jednorazowości, która niesie pocieche najuboższym. Jakby dobrze powiato, toby frunęto to w niebo jak u jakiegoś dzikiego Chagalla: gacie, rajtki, biusthaltery, dżins, chemiczna koronka, cekiny, ztociste badziewko, obcasiki, pumpy i lampasy, tygrysie futra z weglowodorów, wszystko w niebo" (s. 79).

Jest to bieda, która wypływa z nadmiaru, ze zbędności przedmiotów. Autentyczne ubóstwo według Stasiuka potrafiło uruchomić wyobraźnię, ascetyzm sprawiał, że ludzie żyli w pewien sposób pełniej, ponieważ łatwiej potrafili uciekać w marzenia (s. 178). Przedmioty w dawnych czasach były rzeczami wielokrotnego użytku, często mogły występować w innej roli niż była im pierwotnie przypisana. Wszystko mogło być użyteczne, przydatne, wystarczyło tylko być pomysłowym i otworzyć się na wielki potencjał każdego przedmiotu. Dziecięcą fascynację światem rzeczy można dostrzec w opisie zawartości kredensu u wujostwa: „Gumki i blaszki, zgaste na wieki latarki z kolorowymi szkietkami, resztki mecha-

10 COBEL-TOKARSKA, Marta: Bieda Europy Środkowej w narracjach Andrzeja Stasiuka. Kultura i społeczeństwo, 2012, nr 1, s. 57-58.

11 BERNACKI, Marek: Andrzeja Stasiuka przestrzenne doświadczenia Nicości: zapiski z wyprawy mongolskiej. Postscriptum Polonistyczne, 2014, nr 1 (31), s. 85-88. 
nizmów, oddzielne sztućce i końcówki do robienia kietbasy albo kruchych ciastem, potem nożyki, osetki, klamerki, cyna i kalafonia, czernidto i klej, paski do zegarków z matymi kompasami, płaskie baterie, soczewki, btękitna farbka do pościeli, pomarańczowe wentyle, klapcażki, kapslownice $i$ korkociagi, istna robinsonia i samowystarczalność domu z pogranicza" (s. 43).

Przedmioty służyły człowiekowi, były człowiekowi poddane, a z drugiej strony człowieka nie można było pojąć bez przedmiotów, które człowieka otaczają. ${ }^{12}$ Współczesny nadmiar przeciwnie - blokuje wyobraźnię, zakleja umysł, wypełnia wszystko cynfolią, pozłotkiem, podażą i dystrybucją (s. 187), więzi człowieka i ogranicza go.

Stasiuk opisuje szczegółowo chiński sklep, wypełniony towarami, których przeznaczenie, oprócz samego istnienia, pozostaje tajemnica (s. 227). Jest to swego rodzaju mikroświat, przepełniony tym, co zbędne. Jest to wysypisko tanich, nikomu niepotrzebnych cudów (s. 274), które jednak znajdują swoich nabywców. Stasiuk wyjaśnia powód swoich peregrynacji do chińskich sklepów: „Po to tu przyjeżdzatem. Dla nauki. Żeby ogladać przedmioty, których żywot jest niekonieczny $i$ chwilowy, bo zaraz się rozkrusza, rozkleja, ztamia, rozleca, zbiegna i rozciagna, ale na ich miejsce czekaja już nastepne, stoja w niekończacej się kolejce, aby zastapić martwych towarzyszy i koić człowiecza samotność, sycić nasz wzrok $i$ dotyk, i pragnienie posiadania" (s. 228).

Każdy przedmiot zawiera w sobie jednorazowość, prowizoryczność, jest to „obfitość nicości” (s. 228), która przytłacza, ale także pełni funkcje terapeutyczne - koi frustracje, niweluje niepowodzenia. Cykl wybierania, kupowania i zużywania tłumi ludzki lęk przed śmiercią, przed przemijaniem, jest tanim lekarstwem na całe zło świata. Jednakże przedmioty te jedynie napędzają pragnienia, generują dalszą chęć kupowania, przez nie człowiek już nigdy nie zazna ukojenia ani zaspokojenia (s. 229). Pewnym przedobrazem chińskich sklepów są dla Stasiuka jarmarki i odpusty z czasów jego dzieciństwa, które służyły wyrwaniu człowieka z codzienności i powszedniości. Jednakże chińskie sklepy, cały czas obecne w kulturowym krajobrazie współczesnego świata, same stają się codziennością i powszednieją. Tym samym eseje Stasiuka stają się opowieścią o ludzkim nienasyceniu, o żądzy posiadania, o niespełnieniu.

\section{Przedmioty nasiąknięte zapachami i ciężkie (s. 12)}

W esejach Stasiuka ważne miejsce zajmuje również stosunek do przeszłości. Skomplikowana, zapętlona przeszłość Europy Środkowej i Europy Wschodniej jest obecna także w sferze materialnej. Przeszłość nie jest czymś, co przemija, kończy się, ale, jak pisze Olsen, nie zostaje z tyłu, gromadzi się i składa się na stająca się teraźniejszość. ${ }^{13}$ Przedmioty są właśnie łącznikami między tym, co było, a tym, co jest. Stają się świadectwem przeszłości. Często są to rzeczy porzucone, zabrane, ukradzione, przedmioty odsunięte na dalszy plan, przedmioty, które stają się „ocalatymi zbędnościami przesztości”. ${ }^{14}$ Artefakty

12 RAKOWSKI, Tomasz: Antropologia rzeczy: wprowadzenie. Op. cit., s. 7.

13 OLSEN, Bjørnar: W obronie rzeczy. Archeologia i ontologia przedmiotów. Op. cit., s. 196.

14 Tamże, s. 255. 
te upodabniają się do palimpsestu. Są w nich obecne kolejno nakładające się na siebie warstwy, sa jak pień drzewa, który stopniowo obrasta w słoje. Przedmioty wydają się być także wyznacznikami płynącego czasu, ${ }^{15}$ zużywają się, zmieniają z potrzebnych niepotrzebne, aby potem znów stać się użytecznymi. Wchłaniają w siebie upływające życie. Tak jest na przykład ze sklepowymi ladami i szafami, które pozostały z łemkowskiej wsi: „Drewno $i$ sklejka byty tluste od dotyku rak i rzeczy, nasiaknięte zapachami i cięzkie. Życie w nie weszto $i$ zastygto. Warstwy życia: temkowszczyzna, komunizm i teraz my, spoceni od tego cięaru" (s. 12). Stare, zużyte przedmioty przypominają bursztyn, w którym została zatrzymana przeszłość, są niemym świadkiem i świadectwem przeszłości. W podobny sposób cudem ocalałe przed historią są belki z łemkowskich chałup. Na belkach tych wyryte były daty, trójramienne krzyże i symbole solarne (s. 13). Właśnie te belki stały się budulcem stodół i pegeerowskich zabudowań, tworząc dziwny palimpsest, w którym elementy starych cerkwi i łemkowskich chałup stawały się podstawą nowego systemu (s. 33). Dochodziło do przedziwnego recyklingu rzeczy, coś, co odrzucone, zniszczone zmieniało się w nowe.

Przedmioty odzwierciedlaja przemiany społeczne, są jak lustra, w których przegląda się czas. Stasiuk pokazuje zmianę systemu politycznego i zmiany społeczne właśnie z wykorzystaniem materialności przedmiotów i zawartych w niej znaczeń. Obrazowo pokazuje transformacje po 1989 roku: „W tamtych dniach chtopi zajeżdzali ciagnikami i tadowali na przyczepy kotchozowa graciarnię: resztki maszyn, narzędzi, kawatki różnych sprzętów, zwoje kabli, blaszane beczki, gumowe węze, miazgę kolektywizmu, z której indywidualizm potrafit jeszcze sklecić coś przydatnego" (s. 33).

Znowu pojawia się motyw recyklingu rzeczy, ich ponownego użycia. Pojawia się pewnego rodzaju szacunek do przedmiotu, przedmiotu, który można ponownie wykorzystać. Bardzo wyraźnie rysuje się tu jako kontrapunkt jednorazowość, przemijalność chińskich towarów, których nie sposób ponownie użyć. Odpadki, śmieci po dawnej epoce stają się podstawą nowego świata indywidualizmu, w którym dochodzi do spontanicznego, ponownego wykorzystywania przedmiotów, do przesunięć i przemian rzeczy. ${ }^{16}$ Świat ten jednak nie mógł się w pełni rozwinąć, przynajmniej na poziomie rzeczy, przytłoczony nawałami, naręczami, stosami przedmiotów importowanych z Chin.

Rzeczy wynurzające się z przeszłości są także świadectwem traum. Świecą u Stasiuka złowrogim blaskiem, emanują złą energią, jak w przypadku złota, kosztowności pozostałych po zgładzonych Żydach. Stasiuk w przejmujący sposób opisuje powojenne poszukiwania złota w popiołach, doskonale oddaje psychologię biedaków z polskich wsi i miasteczek, którzy decydują się na ten krok, aby poprawić swoją nędzną egzystencję: „Bo przecież niczyje leży w poktadach popiotów, które sa jak przedwieczny minerat, jak geologia: wapń, krzem, potas, pierwiastki, a nie żadne życie. Więc niczyje, zostawione na przepadek, bo ziemia wchtonie gtębiej i gtębiej, i na wieki wieków, i nikomu nic do tego. Tak. Bo ich już nie ma tak bardzo, jakby nigdy nie byto. [...] Więc przymykam powieki i widze, jak rozkopuja i grzebia, czujni, niewinni i zachtanni" (s. 110-111).

15 KRAJEWSKI, Marek: Przedmiot, który ucztowiecza... Op. cit., s. 52.

16 RAKOWSKI, Tomasz: Przemiany, przesuniecia, przedmioty przejściowe. Antropologia rzeczy. Kultura Współczesna, 2008, nr 3, s. 61. 
Jednak pożydowskie złoto ma gęstą, ciemną, magiczną aurę, można za nie wprawdzie wybudować większy dom, żyć zamożniej, ale jest to życie z połkniętą trucizną, o której nie wiadomo, kiedy zadziała, jak pisze obrazowo Stasiuk (s. 112). Są to rzeczy, przedmioty, które oskarżają ${ }^{17}$ mienie, które jest w pewnym sensie echem swoich pierwotnych właścicieli i w jakimś momencie może przemówić ich martwym głosem. Dochodzi tym samym do ciekawego zjawiska - ci, którzy podlegli reifikacji, którzy byli traktowani przedmiotowo, zamienieni w nic nieznaczącą rzecz, odwiezieni pociągami do obozów koncentracyjnych i tam zgładzeni, otrzymują prawo głosu poprzez przedmioty, które także podlegają reifikacji, bo w nich samych odzwierciedla się człowiek, do którego rzeczy owe należały. ${ }^{18}$ Przedmioty są personifikowane, mają moc przekazywania informacji o tym, co tak naprawdę się wydarzyło. Przypominają tykającą bombę, która może w każdym momencie wybuchnąć.

Podobnie jest także w przypadku pożydowskich domów, w których chcą zamieszkać nowi lokatorzy. „Doskonale wiadomo, że dramatyczne zmiany w środowisku rzeczy, spowodowane wojna lub katastrofa naturalna, maja traumatyczne konsekwencje. Utrata dobytku, domu, miasta, farmy czy terenu towieckiego wytwarza brak, z którym trudno pogodzić sie psychicznie." 19 Domy, rzeczy pożydowskie są według Stasiuka przesiąknięte śmiercią, są rzeczami przenikniętymi tłustym, krematoryjnym dymem (s. 88). Według Olsena właśnie przedmioty porzucone, nagle opuszczonych, domostwa pozbawione gospodarzy stają się częstym tematem literackim obrazującym dramat żydowskiej Zagłady, ${ }^{20}$ są symbolami świata, który odszedł. Śmierć pokazana jest jako coś, co przyszło nagle, jest zjawiskiem niesystemowym, a w nagłej śmierci dochodzi do naruszenia jednokierunkowości czasu, jak pisze Ivo Pospísili. ${ }^{21}$ Przedmioty codziennego użytku noszą w sobie znamię rozkładu i zniszczenia, są świadectwem traum, o których żyjący na próżno starają się zapomnieć. „'A co? Miato tak leżec?? A co? Miato tak stac?' Więc weszliśmy w ich życie, nie dzielac ich losu, bo któż by chciat albo śmiat? Żyjemy na zgliszczach, mamy zweglona, martwa pamięć. Pusta. [...] Weszliśmy do cudzych domów $i$ w szafach rozktadaliśmy nasze rzeczy. [...] Patrzyliśmy przez cudze okna, myślac, że to jest nasz widok" (s. 88-89).

Pojawia się tu często eksponowany motyw pustki zapełnianej czymś nowym, pustki, która mówi za pośrednictwem oskarżających przedmiotów. ${ }^{22}$

Stasiuk, podobnie jak Bożena Schallcross, autorka fundamentalnej monografii poświęconej zagadnieniom rzeczy i Holocaustu pt. „Rzeczy i Zagłada”, stara się odnaleźć zatarte ślady zmarlych i odtworzyć żywotną więź między człowiekiem a przedmiotem. ${ }^{23}$

17 PIOTROWIAK-JUNKIERT, Kinga: Rzeczy ż... O wojennych $i$ powojennych lekturach przedmiotów. Ginczanka, Ficowski, Mezei, Borbély. In: DZIEWOŃSKA-KISS Dorota - JANIEC-NYITRAI, Agnieszka - RÁDULY, Zsuzsanna (eds.): Polono-Hungarica 2016, Budapest: Lengyel Filológiai Tanszék, 2016, s. 249.

18 MIKOŁAJCZYK-WOJCIECHOWSKA, Natalia: Symfonia rzeczy. Funkcje opisów przedmiotów w prozie Stefana Chwina. Acta Universitatis Wratislaviensis. Prace Literackie XLVII, 2007, s. 210.

19 OLSEN, Bjørnar: W obronie rzeczy. Archeologia i ontologia przedmiotów. Op. cit., s. 243.

20 Tamże, s. 143.

21 POSPÍŠIL, Ivo: Prostorovost/ spaciálnost/ areálovost literatury. World Literature Studie 19, 2010, nr 2, s. 63.

22 PIOTROWIAK-JUNKIERT, Kinga: Rzeczy ż... O wojennych $i$ powojennych lekturach przedmiotów. Ginczanka, Ficowski, Mezei, Borbély. Op. cit., s. 245-246.

23 SCHALLCROSS, Bożena: Rzeczy i Zagtada. Kraków: Universitas, 2010, s. 25. 
W obrazach rozkładu i przemijalności ludzkiego życia pojawia się częsta w utworach pisarza melancholia i nostalgia, doświadczenie straty i nieodwracalnego końca. ${ }^{24}$ Stasiuk jednocześnie zwraca uwagę na wielonarodowość Europy Środkowej, na istotny czynnik żydowski, który wpływał na rozwój tego regionu. ${ }^{25}$

\section{Podsumowanie}

Przedmioty osadzają człowieka w świecie, stabilizują jego istnienie, mają istotny wpływ na ludzkie zwyczaje, mają wpływ na kształt kultury, jak podkreśla przywołany już norweski badacz B. Olsen: „Wytonienie się rozpoznawalnych struktur czy instytucji wymaga nie tylko sieci relacji pomiędzy jednostkami, ale i stabilności, konkretności i bezpieczeństwa, innymi stowy - rzeczy. Poprzez nasza wymiane z rzeczami nasze zwyczaje i czynności staja sie standardowe $i$ przewidywalne, tworza to, o czym lubimy myśleć jako o strukturach $i$ instytucjach (spotecznych). Pozbawione namacalności i uporczywości rzeczy, struktury te ulegtyby erozji." ${ }^{26}$

Przedmioty, stanowiąc więc istotny budulec rzeczywistości, są jak beton scalający niepewność i chwiejność świata, jednocześnie to właśnie one pozwalają uchwycić ową efemeryczność pewnych idei, ulotność dyskursów, amorfię rzeczywistości. To właśnie zwracając się ku rzeczom, przedmiotom, produktom i towarom Stasiuk potrafi dostrzec i opisać niekiedy trudno dostrzegalne zmiany współczesnego świata. Rację ma Marta Cobel-Tokarska, która zauważa, że Stasiuk zdecydowanie oddaje głos przedmiotom, częściej opisuje pejzaże i rzeczy, niż ludzi. ${ }^{27} \mathrm{~W}$ esejach podróżniczych jest to jeszcze wyraźniej widoczne. Przedmioty, które pisarz spotyka podczas swoich podróży, mają moc przywracania wspomnień i ciągłego odnawiania przeszłości, taki właśnie jest jeden z celów wypraw pisarza. $^{28}$

Stasiuk zwracając uwagę na istotność materialnego świata rzeczy wielokrotnie w swoich esejach potwierdza stanowisko Olsena, który pisze wprost: „Wierze, że materialny świat istnieje, a rzeczy konstytuuja podstawowy i staty element naszej egzystencji. Rzeczy, materiaty, krajobraz maja konkretne wtaściwości oddziatujace $i$ ksztattujące zarówno nasza ich percepcje, jak i nasze z nimi wspótzamieszkiwanie." ${ }^{29}$ Człowiek wytwarza rzeczy, ale również jest wytwarzany poprzez rzeczy, kształtowany poprzez to, co go otacza. ${ }^{30}$ Świat Stasiuka zbudowany jest z konkretu, jego pisarstwo cechuje nieufność do nieokreślonego, dlatego właśnie punktem wyjścia jego rozważań są właśnie realnie istniejące przedmioty, które tworza

24 LECH, Jacek: Patrzac na mape, spogladam w nicość. Wokót melancholii i nudy w wybranych tekstach prozatorskich Andrzeja Stasiuka. Tematy i konteksty, 2015, nr 5, s. 48-50.

25 ZELENKA, Miloš: Koncepce středni Evropy v slovansko-mad’arských souvislostech. Slavica litteraria 14, 2011, nr 1, s. 88.

26 OLSEN, Bjørnar: W obronie rzeczy. Archeologia i ontologia przedmiotów. Op. cit., s. 217.

27 COBEL-TOKARSKA, Marta: Bieda Europy Środkowej w narracjach Andrzeja Stasiuka. Op. cit., s. 61.

28 KOŁODZIEJCZYK, Dorota: "The Slavic on the road" - Eastern European negative nativism in Andrzej Stasiuk's travelogues. Kultura-Historia-Globalizacja, 2010, nr 7, s. 101.

29 OLSEN, Bjørnar: W obronie rzeczy. Archeologia i ontologia przedmiotów. Op. cit., s. 11.

30 KRAJEWSKI, Marek: Przedmiot, który ucztowiecza... Op. cit., s. 43. 
mozaikę, pewien fragmentaryczny obraz, pewną wizję, która, jak stwierdza Adam F. Kola nie rości sobie prawa do uniwersalności, ${ }^{31}$ ale jednocześnie podaje świadectwo o przemianach współczesnego świata.

\section{Bibliografia}

BERNACKI, Marek: Andrzeja Stasiuka przestrzenne doświadczenia Nicości: zapiski z wyprawy mongolskiej. Postscriptum Polonistyczne 31, 2014, nr 1, s. 81-92.

COBEL-TOKARSKA, Marta: Bieda Europy Środkowej w narracjach Andrzeja Stasiuka. Kultura i społeczeństwo, 2012, nr 1, s. 51-80.

DOMAŃSKA, Ewa: Humanistyka nie-antropocentryczna a studia nad rzeczami. Kultura Współczesna, 2008, nr 3, s. 9-21.

DOMAŃSKA, Ewa: Problem rzeczy we wspótczesnej archeologii. In: KOWALEWSKI, Jacek - PIASEK, Wojciech - ŚLIWA, Marta (eds.): Rzeczy i ludzie. Humanistyka wobec materialności. Olsztyn: Instytut Filozofii Uniwersytetu Warmińsko-Mazurskiego w Olsztynie, 2008, s. 27-60.

HEIDEGGER, Martin: Rzecz. Odczyty i rozprawy, Kraków: Aletheia, 2002, s. 145-164.

KOLA, Adam F.: Europa w dyskursie polskim, czeskim i chorwackim. Rekonfiguracje krytyczne. Toruń: Wydawnictwo Naukowe Uniwersytetu Mikołaja Kopernika, 2011.

KOŁODZIEJCZYK, Dorota: "The Slavic on the road" - Eastern European negative nativism in Andrzej Stasiuk's travelogues. Kultura-Historia-Globalizacja, 2010, nr 7, s. 97-108.

KRAJEWSKI, Marek: Przedmiot, który ucztowiecza... Kultura Współczesna, 2008, nr 3, s. 43-54.

LECH, Jacek: Patrzac na mape, spogladam w nicość. Wokót melancholii i nudy w wybranych tekstach prozatorskich Andrzeja Stasiuka. Tematy i konteksty, 2015, nr 5, s. 46-59.

MIKOŁAJCZYK-WOJCIECHOWSKA, Natalia: Symfonia rzeczy. Funkcje opisów przedmiotów w prozie Stefana Chwina. Acta Universitatis Wratislaviensis. Prace Literackie XLVII, 2007, s. 209-229.

OLSEN, Bjørnar: W obronie rzeczy. Archeologia i ontologia przedmiotów. Warszawa: Wydawnictwo Instytutu Badań Literackich PAN, 2013.

PIOTROWIAK-JUNKIERT, Kinga: Rzeczy ż... O wojennych i powojennych lekturach przedmiotów. Ginczanka, Ficowski, Mezei, Borbély. In: DZIEWOŃSKA-KISS, Dorota - JANIEC-NYITRAI, Agnieszka - RÁDULY, Zsuzsanna (eds.): Polono-Hungarica 2016, Budapest: Lengyel Filológiai Tanszék, 2016, s. 245-256.

POSPÍŠIL, Ivo: Prostorovost/ spaciálnost/ areálovost literatury. World Literature Studies 19, 2010, nr 2, s. 61-73.

RAKOWSKI, Tomasz: Antropologia rzeczy: wprowadzenie. Kultura Współczesna, 2008, nr 3, s. 5-8.

RAKOWSKI, Tomasz: Przemiany, przesunięcia, przedmioty przejściowe. Antropologia rzeczy. Kultura Współczesna, 2008, nr 3, s. 55-7.

SCHALLCROSS, Bożena: Rzeczy i Zagtada. Kraków: Universitas, 2010.

STASIUK, Andrzej: Wschód. Wołowiec: Czarne, 2014.

31 KOLA, Adam F.: Europa w dyskursie polskim, czeskim i chorwackim. Rekonfiguracje krytyczne. Toruń: Wydawnictwo Naukowe Uniwersytetu Mikołaja Kopernika. s. 72. 
SZYDŁOWSKA, Joanna: Retoryka rzeczy a proces zadomowienia w przestrzeniach pojattańskiego Okcydentu. Anthropos, 2011, nr 16-17, s. 127-141.

ZELENKA, Miloš: Koncepce středni Evropy v slovansko-mad'arských souvislostech. Slavica litteraria 14, 2011, nr 1, s. 87-94.

\section{PhDr. Agnieszka Janiec-Nyitrai, PhD.}

Ústav slovanské a baltské filologie, Univerzita L. Eötvöse 1088 Budapešt', Múzeum krt. 4/D., Mad’arsko janiec.nyitrai@gmail.com 